\title{
Influence of familial status on medical graduates' motivation for choosing a surgical career
}

\author{
Bárbara Calixto^, Fernando Augusto Mardiros Herbella^, Fernanda Marino Lafraia^, Francisco Schlottmann^, \\ Marco G. Patti^
}

Department of Surgery, Federal University of São Paulo, São Paulo, Brazil

Contributions: (I) Conception and design: FAM Herbella; FM Lafraia; (II) Administrative support: None; (III) Provision of study materials or patients: None; (IV) Collection and assembly of data: None; (V) Data analysis and interpretation: None; (VI) Manuscript writing: All authors; (VII) Final approval of manuscript: All authors.

Correspondence to: Dr. Fernando Augusto Mardiros Herbella. Department of Surgery, Escola Paulista de Medicina, Rua Diogo de Faria 1087 cj 301 Sao Paulo, SP 04037-003, Brazil. Email: herbella.dcir@epm.br.

Background: Medical students' interest in surgery is declining. The identification of factors that influence the choice of specialty may be used to create strategies to increase its attractiveness. This study aims to determine the influence of familial status on medical students' motivation for choosing surgical career.

Methods: We prospectively surveyed medical students from the last 2 years of medical school regarding their career choice for residency and familial status. We sent a questionnaire to 149 students regarding: demographic data, the type of program chosen for residence, and the main motivation for their choice.

Results: The programs chosen for the area of residence were: general surgery for 16 (11\%), other areas for $100(67 \%)$ students [18 (18\% of other areas, $12 \%$ of the total) internal medicine; 15 (15\% of other areas, $10 \%$ of the total) gynecology and obstetrics; 13 (13\% of other areas, $9 \%$ of the total) otorhinolaryngology/ ophthalmology; 13 (13\% of other areas, $9 \%$ of the total) pediatrics; 10 (10\% of other areas, $7 \%$ of the total) psychiatry, 4 (4\% of other areas, $3 \%$ of the total) orthopedics, and 25 ( $25 \%$ of other areas, $17 \%$ of the total) others] and 33 (22\%) had not made a choice. Demographic data was similar between the groups. Motivation for choosing the program was only based on personal satisfaction. Familial status (family history on medicine and family income) was not different between groups.

Conclusions: Familial status did not influence the students' choice of a surgical career. The only important motivation was the personal satisfaction.

Keywords: Familial status; familial influence; surgical career; choice of specialty

Received: 25 January 2021; Accepted: 14 April 2021; Published: 30 June 2021.

doi: $10.21037 /$ asj-21-2

View this article at: http://dx.doi.org/10.21037/asj-21-2

\section{Introduction}

Different countries face an uneven distribution of medical specialties (1). Of note, the interest in a surgical career is certainly declining in some countries (2-4), and a recent systematic review (5) showed that various factors may affect choice of surgery as a career, mainly gender, features of surgical education, and acceptance of surgical lifestyle are the most important factors. The identification of the reasons that lead to the decision making process of choosing a surgical career may be used to create strategies to increase the attractiveness of this career. Familial status (family history in the medical career, family income) is a topic not well-studied as motivation to pursue a surgical career.

^ ORCID: Bárbara Calixto, 0000-0002-7806-7673; Fernando Augusto Mardiros Herbella, 0000-0003-3594-5744; Fernanda Marino Lafraia, 0000-0002-8504-1455; Francisco Schlottmann, 0000-0003-3565-0559; Marco G. Patti, 0000-0001-5181-8572. 
This study aims to determine the influence of familial status on medical students' motivation for choosing a surgical career. We present the following article in accordance with MDAR and STROBE reporting checklists (available at https://asj.amegroups.com/article/ view/10.21037/asj-21-2/rc).

\section{Methods}

We prospectively surveyed medical students from the last 2 years of medical school regarding career choice for residency and familial status.

\section{Setting}

The study was conducted at an academic medical center with a 750-bed quaternary hospital, located in Sao Paulo, Brazil, the 4th largest metropolis in the world. The institution is a mixed public and private hospital. There are 92 residency programs, and the medical school enrolls 120 students annually.

\section{Population}

Medical students from the fifth and sixth year of medical school were surveyed. We recruited 150 students out of the 240 current in the fifth and sixth years, through a probabilistic random sample. One student refused to participate.

\section{Questionnaire}

The dedicated and original questionnaire was divided into: (I) demographic data (gender, age, family income, family history in the profession); (II) program chosen for the area of residence (internal medicine, general surgery, gynecology and obstetrics, psychiatry, pediatrics, orthopedics, ophthalmology/otorhinolaryngology, and "not yet chosen"); and (III) motivation for choosing the program (personal satisfaction, financial perspective, quality of life, difficulty of the residency program). Only one answer was allowed for each question. The mean value of family income was used as the dichotomization point (10 minimum wages).

The questionnaire was applied in person by one of the authors who is a medical student to prevent hierarchical bias.

\section{Ethics}

The project was approved by the ethics committee of Federal University of São Paulo (CAAE: 83017418.7.0000.5505; CEP: 0106.0037.02/2018), and all participants signed a consent form before enrolling in the study. The identity of the participants was kept anonymous. The study was conducted in accordance with the Declaration of Helsinki (as revised in 2013).

\section{Statistics}

Data were transferred to Excel 365 (Microsoft Corporation, Redmond, WA) and then analyzed for statistical significance using Prism 8 (GraphPad Software, San Diego, CA, USA).

Descriptive statistics were calculated for all data. The students were divided into two groups for comparisons: those who chose general surgery as a specialty and those who chose other specialties. Towards the family income, the value of 10 minimum wages was considered a cut off.

Student's $t$ test was used to evaluate continuous variables and the Fisher's test was used to evaluate categorical variables. Variables are expressed as mean \pm standard deviation (range) or $\mathrm{n}(\%)$. A $\mathrm{P}$ value of less than 0.05 was considered significant.

\section{Results}

A total of 149 students participated: $86(58 \%)$ students were females, $60(40 \%)$ males and $3(2 \%)$ chose not to answer about gender. The average age was 25 (range, 20-33) years.

$33(22 \%)$ students have not yet decided on the residency program to follow and they were excluded from further analysis. The programs chosen for the area of residence by others were: general surgery for $16(11 \%)$ and other areas for $100(67 \%)$ students [18 (18\% of other areas, $12 \%$ of the total) internal medicine; 15 (15\% of other areas, $10 \%$ of the total) gynecology and obstetrics; 13 (13\% of other areas, $9 \%$ of the total) otorhinolaryngology/ophthalmology; 13 (13\% of other areas, $9 \%$ of the total) pediatrics; 10 (10\% of other areas, $7 \%$ of the total) psychiatry, 4 (4\% of other areas, $3 \%$ of the total) orthopedics, and 25 (25\% of other areas, $17 \%$ of the total) others].

The answers for the group who chose General Surgery as a specialty as compared to the other specialties are listed in Table 1. Demographic data was similar between the groups. Motivation for choosing the program was only different for personal satisfaction. Familial status (family history of a career in medicine and family income) was not different between groups. 
Table 1 Comparison between general surgery and other specialties' groups: sociodemographic data and motivation factors for career

\begin{tabular}{|c|c|c|c|c|}
\hline & General surgery group & Other specialties group & Total & $P$ value \\
\hline Female & $7(43.7)$ & $79(59.4)$ & $86(57.7)$ & \\
\hline Male & $9(56.3)$ & $51(38.3)$ & $60(40.3)$ & \\
\hline Not declared & 0 & $3(2.3)$ & $3(2.0)$ & \\
\hline Minimum & 22 & 20 & - & \\
\hline Maximum & 30 & 33 & - & \\
\hline Average & 25 & 25 & 25 & \\
\hline Year of medical school, n (\%) & & & & 1.000 \\
\hline \multicolumn{5}{|l|}{ Motivation, n (\%) } \\
\hline Not yet chosen & 0 & $27(20.3)$ & $27(18.1)$ & - \\
\hline Difficulty of the residency program & 0 & $1(0.7)$ & $1(0.7)$ & 1.000 \\
\hline Financial perspective & $1(6.2)$ & $1(0.7)$ & $2(1.4)$ & 0.203 \\
\hline Quality of life & 0 & $25(18.8)$ & $25(16.8)$ & 0.074 \\
\hline Personal satisfaction & $15(93.7)$ & $79(59.4)$ & $94(63.1)$ & 0.005 \\
\hline Family income, n (\%) & & & & 0.431 \\
\hline$>10$ minimum wages & $7(43.7)$ & $74(55.6)$ & $81(54.4)$ & \\
\hline
\end{tabular}

\section{Discussion}

In the last years, a decrease in interest in surgical career among medical students has been noticed (6). In fact, in our survey, only $10 \%$ of the students chose General Surgery as career. This decline is multifactorial (7) and a recent systematic review and meta-analysis (8) involving 75 studies with 882,209 medical students found twelve possible factors (academic interests, competencies, controllable lifestyle, patient service orientation, medical teachers or mentors, career opportunities, workload, income, length of training, prestige, advice from others and student debt) that influence for or against the choice for surgical career. Few studies, however, have previously analyzed the influence of familial status and family history in the profession on the choice of residency.

\section{Profile of medical students prone for a surgical career}

In our survey, most medical students were female-a trend observed locally since 2010 (9). This female predominance in medical graduation also occurs in other countries, but it was not usually extended to surgical residencies according to some authors (10-12). In our study there was no difference in gender between those who opted or not for a surgical residency. This may be related to a progressive decrease in gender differences in the fields of education and work manifested in the local environment.

All students were between 20-33 years old. All of 
them are part of the so-called Generation Y, that includes individuals who were born between 1980 and 2000. The major characteristics of this demographic group are that they are avid users of technology, want to learn with mentoring and hands-on, to have a job where they can make a difference, but with flexibility and prioritizing lifestyle and work-life balance $(4,13)$. These characteristics may be incompatible with a surgical career, due to the extensive personal dedication and high workload characteristic of the field of surgery $(14,15)$. In 2017 , using a nationally representative sample in the United States Zubair et al. (16) evaluated the perceived work-related quality of life of general surgery residents. They showed that, although subjected to a stressful work environment, surgery residents were satisfied and motivated about their career choice. In our study, personal satisfaction was the only factor statistically significant as motivation for choosing General Surgery. Studies at the beginning of the century showed an important role of financial perspective in the career as motivation for choosing surgery $(17,18)$. Indeed, career opportunities kept the field of surgery attractive at that time (19). We surveyed surgical residents regarding professional expectations in 2 different moments to find that current residents are less worried about financial perspectives as compared to one decade ago $(20,21)$. This corroborates the finding of this study that financial perspective does not guide the choice of surgery.

\section{Influence of familial status on motivation for choosing a surgical career}

Few studies addressed familial influence on the choice of a medical specialty. Even larger studies, such as a systematic review (5) and a meta-analysis (8), did not contemplate this topic.

We hypothesized that family income would significantly influence the decision of a career in surgery. We believed that individuals from lower income families would pursue more lucrative specialties. In fact, a recent paper with African American medical students pointed out that students with large amounts of debt, those who were first generation students to attend college/medical school or those expected to contribute to their family income said that money would be major decision point in deciding a career path (22). Family income was not however, linked to this decision in our population. Ibrahim et al. (23) compared characteristics that influence the choice of a medical or surgical specialty, including the familial history in the medical field. They found that students who had physicians in the family did not want to pursue obstetrics \& gynecology, ophthalmology or emergency medicine. They did not find a correlation between having a physician in the family and pursuing or not General Surgery though. According to Guraya et al. (24) the factors that most influence the selection of specialty are related to own expectations, skills, and to the medical fields with innovative technologies, but the influence of family is not significant on this choice. Interestingly and different from the other studies, Goldin et al. (25) found that having a surgeon in the family increased the likelihood of a student pursuing surgery, while having a non-surgical physician in the family decreased this likelihood. Interestingly, a survey of the American College of Surgeons members disclosed that half of the surgeons do not recommend their children to pursue a career on medicine (26). In our study, family history in the profession was rare and it was not different in incidence between those who want to those who does not want a surgical career.

\section{Study limitations}

Our study has some limitations. First, the number of individuals included is not large. In the cited meta-analysis (8) for example, the average number of participants per study was 243. We had the limitation of the total number of medical students enrolled at the university. Thus, we designed the study to compare surgical versus non-surgical groups irrespective of the specialties in the non-surgical group since the number of participants would be too small for statistical power. Future multicenter study could add more statistical power.

Another question to raise is the regionalism. The setting of the study is the largest city in the country, densely populated, with multicultural influences and easy access to technology, science and innovations, so the results may not be universally valid. In our country, 'general surgery' is defined as a rotation among surgical specialties as a prerequisite for any other surgical specialty (vascular, gastrointestinal, thoracic, cardiac, pediatric, urology, oncologic, etc.). Other more specific specialties that also perform operations (neurosurgery, orthopedics, gynecology/ obstetrics, ophthalmology, otolaryngology, etc.) have direct ingress into the specialty, as such they were not included in the analysis as 'general surgery'.

\section{Conclusions}

In our sample, familial status did not influence the students 
on the choice of surgical career. The only significant motivation was personal satisfaction.

This study demonstrated that despite belonging to the Generation $Y$ with its lifestyle peculiarities, surgery, a demanding specialty, is chosen based on personal satisfaction. Medical students currently do not search for financial perspectives or are influenced by familial variables choosing surgery as a career. This data can be used by educators to promote a more attractive surgical environment in order to achieve personal satisfaction.

\section{Acknowledgments}

Funding: None.

\section{Footnote}

Reporting Checklist: The authors have completed the MDAR and STROBE reporting checklists. Available at https://asj. amegroups.com/article/view/10.21037/asj-21-2/rc

Data Sharing Statement: Available at https://asj.amegroups. com/article/view/10.21037/asj-21-2/dss

Conflicts of Interest: All authors have completed the ICMJE uniform disclosure form (available at https://asj.amegroups. com/article/view/10.21037/asj-21-2/coif). FAMH serves as an unpaid editorial board member of AME Surgical fournal from February 2021 to January 2023 . The other authors have no conflicts of interest to declare.

Ethical Statement: The authors are accountable for all aspects of the work in ensuring that questions related to the accuracy or integrity of any part of the work are appropriately investigated and resolved. The project was approved by the ethics committee of Federal University of São Paulo (CAAE: 83017418.7.0000.5505; CEP: 0106.0037.02/2018), and all participants signed a consent form before enrolling in the study. The identity of the participants was kept anonymous. The study was conducted in accordance with the Declaration of Helsinki (as revised in 2013).

Open Access Statement: This is an Open Access article distributed in accordance with the Creative Commons Attribution-NonCommercial-NoDerivs 4.0 International License (CC BY-NC-ND 4.0), which permits the noncommercial replication and distribution of the article with the strict proviso that no changes or edits are made and the original work is properly cited (including links to both the formal publication through the relevant DOI and the license). See: https://creativecommons.org/licenses/by-nc-nd/4.0/.

\section{References}

1. Kumwenda B, Cleland J, Prescott G, et al. Relationship between sociodemographic factors and specialty destination of UK trainee doctors: A national cohort study. BMJ Open 2019;9:e026961.

2. Peel JK, Schlachta CM, Alkhamesi NA. A systematic review of the factors affecting choice of surgery as a career. Can J Surg 2018;61:58-67.

3. Shelton J, Obregon M, Luo J, at al. Factors Influencing a Medical Student's Decision to Pur-sue Surgery as a Career. World J Surg 2019;43:2986-93.

4. Businger A, Villiger P, Sommer C, et al. Arguments for and against a career in surgery: A qualitative analysis. Ann Surg 2010;252:390-6.

5. Schmidt LE, Cooper CA, Guo WA. Factors Influencing US Medical Students' Decision to Pursue Surgery. J Surg Res 2016;203:64-74.

6. Berman L, Rosenthal MS, Curry LA, et al. Attracting Surgical Clerks to Surgical Careers: Role Models, Mentoring, and Engagement in the Operating Room. J Am Coll Surg 2008;207:793-800, 800.e1-2.

7. Gawad N, Moussa F, Christakis GT, et al. Planting the "SEAD": Early comprehensive expo-sure to surgery for medical students. J Surg Educ 2013;70:487-94.

8. Yang Y, Li J, Wu X, et al. Factors influencing subspecialty choice among medical students: A systematic review and meta-analysis. BMJ Open 2019;9: e022097.

9. Scheffer MC, Guilloux AGA, Matijasevich A, et al. The state of the surgical workforce in Brazil. Surgery 2017;161:556-61.

10. Fitzgerald JEF, Tang SW, Ravindra P, et al. Gender-related perceptions of careers in surgery among new medical graduates: Results of a cross-sectional study. Am J Surg 2013;206:112-9.

11. Cochran A, Hauschild T, Elder WB, et al. Perceived gender-based barriers to careers in aca-demic surgery. Am J Surg 2013;206:263-8.

12. Baxter N, Cohen R, McLeod R. The impact of Gender the Choice of Surgery as a Creer. Am J Epidemiol 1987;126:363.

13. McLeod RS. SSAT presidential address 2014: here comes Generation Y! J Gastrointest Surg 2015;19:1-5. 
14. Yeo H, Viola K, Berg D, et al. Attitudes, training experiences, and professional expectations of US general surgery residents: a national survey. JAMA 2009;302:13018. Erratum in: JAMA 2009;302:2322.

15. Dyrbye LN, Burke SE, Hardeman RR, et al. Association of clinical specialty with symptoms of burnout and career choice regret among US resident physicians. JAMA 2018;320:1114-30. Retraction in: JAMA 2019 Mar 26;321:1220-1.

16. Zubair MH, Hussain LR, Williams KN, et al. WorkRelated Quality of Life of US General Surgery Residents: Is It Really so Bad? J Surg Educ 2017;74:e138-46.

17. Newton DA, Grayson MS, Thompson LF. The variable influence of lifestyle and income on medical students' career specialty choices: Data from two U.S. medical schools, 1998-2004. Acad Med 2005;80:809-14.

18. Thornton J, Esposto F. How important are economic factors in choice of medical specialty? Health Econ 2003;12:67-73.

19. Azizzadeh A, McCollum CH, Miller CC 3rd, et al. Factors influencing career choice among medical students interested in surgery. Curr Surg 2003;60:210-3.

20. Lafraia FM, Herbella FAM, Kalluf JR, et al. Attitudes and experiences during training and professional expectations

doi: $10.21037 /$ asj-21-2

Cite this article as: Calixto B, Herbella FAM, Lafraia FM, Schlottmann F, Patti MG. Influence of familial status on medical graduates' motivation for choosing a surgical career. AME Surg J 2021;1:2. in generation-y surgical residents. Rev Assoc Med Bras 2019;65:348-54.

21. Herbella FA, Fuziy RA, Takassi GF, et al. Evaluation of training and professional expecta-tions of surgery residents. Rev Col Bras Cir 2011;38:280-4. English, Portuguese.

22. Roberts SE, Shea JA, Sellers M, et al. Pursing a career in academic surgery among African American medical students. Am J Surg 2020;219:598-603.

23. Ibrahim M, Fanshawe A, Patel V, et al. What factors influence British medical students' ca-reer intentions? Med Teach 2014;36:1064-72.

24. Guraya SY, Almaramhy HH. Mapping the factors that influence the career specialty prefer-ences by the undergraduate medical students. Saudi J Biol Sci 2018;25:1096-101.

25. Goldin SB, Schnaus MJ, Horn G, et al. Surgical interest and surgical match for third-year students: Results of a prospective multivariate longitudinal cohort study. J Am Coll Surg 2012;215:599-606.

26. Shanafelt TD, Balch CM, Bechamps GJ, et al. Burnout and career satisfaction among Ameri-can surgeons. Ann Surg 2009;250:463-71. 